\title{
Assessment of Alien Honeybee Species (Apis florea) in North West and Northern Ethiopia
}

\section{Zewdu $A^{1 *}$, Desalegn $B^{1}$, Amssalu $B^{1}$, Gebreamlak B², Tolera $\mathrm{K}^{1}$}
${ }^{1}$ Oromia Agricultural Research Institute, Holeta Bee Research Center, P.O. Box 22, Holeta, Ethiopia.
${ }^{2}$ Tigray Agricultural Research Institute, Mekelle Agricultural Research Center, P.O. Box 1132, Mekelle, Tigray, Ethiopia.

ARTICLE INFO

Article No.: 012016019

DOI: 10.15580/GJAS.2016.3.012016019

Submitted: 20/01/2016

Accepted: $25 / 01 / 2016$

Published: $28 / 03 / 2016$

*Corresponding Author

Zewdu A

E-mail: zewdu402@yahoo.com

Keywords:

A.florea, nesting habitat, invasion, Tigray, Amhara

\section{ABSTRACT}

The dwarf honeybee (or red dwarf honeybee), Apis florea Fabricius, is native to Southeast Asia. The general distribution of this species is confined to warm climates where it performs very well. The study was carried out to assess the invasion, habitat and its negative effect on local honeybees in North West and Northern Ethiopia. Districts for the study were purposively selected. To undertake the assessment, three different techniques, interviewing local people, observing foraging bees on the field and searching for nests of the alien species were employed. Based on the study results, Metema could be the possible district to which $A$. florea was first introduced in 2003. Since then, this alien bee species has become widely distributed in the lowlands of north Gondar, and central and northern Tigray up to the Eritrean border. Indicating the rapid expansion and effective colonizing ability, they become well adapted to new hot arid conditions of North West and North Ethiopia without being affected by the competition from local honeybees, Apis mellifera. This natural expansion of the species may not have a pronounced negative effect at this time but may pose some threat to the local ecosystem in the future. Therefore, the rapid expansion of the $A$. florea into new habitats has to be monitored and more detailed research is needed to understand their ecological impacts in the new ecosystem and potentially possible economic advantages and disadvantages. 


\section{INTRODUCTION}

The dwarf honeybee (or red dwarf honeybee), Apis florea Fabricius, is one of two small wild honeybee species of southern and southeast Asia (Ruttner, 1988). The dwarf honeybee is confined to warm climates where it does very well (Suwannapong et al, 2011). A. florea is known to have a wider distribution in many tropical and subtropical Asia, especially in Southeast China, India, Burma, Laos, Vietnam, Malaylasia, Indonesia and Philippines (Suwannapong et al, 2011). It is not only confined to this area but also has continuously been expanding west wards from its origin (Ruttner, 1988). It is now present in the Middle East including Iran and very limited distribution in the costal area of southern Iraq and has established abundant populations on the Arabian Peninsula in Oman, Yemen and central Saudi Arabia (Hepburn et al., 2005; Hepburn and Radloff, 2011).

Apart from aforementioned countries, the dwarf honeybee (Apis florea) took inadvertent chance to cross onto another continent, Africa and was observed in Khartoum in 1985 for the first time (Lord and Nagi, 1987; Mogga and Ruttner, 1988). Using this inadvertent opportunity, it is spreading rapidly over most parts of Sudan (Omer, 2007; Mortez et al., 2010). This is the most western distribution of the species and first in its expansion in Africa.

Recently, in 2011, A. florea was trapped from Persicaria setosula flowers along the River Zarima in Northern Gondar, Ethiopia (Pauly and Zewdu, 2013). It was discovered here for the first time in northern Ethiopia. More recently, Bezabih et al. (2014) reported the invasion of 15 localities by $A$. florea in Tigray Region. These evidences make Ethiopia the second invaded country in Africa.

On the other hand, the areas where this species is suspected and investigated are also an area for native bee species Apis mellifera. A. florea populations can invade areas where even native $A$. mellifera populations are densely populated with apparently no obstacle for the range of expansion (EI Shafie et al., 2002). Therefore, the spread of $A$. florea might have some concern for apiculture since $A$. florea has been reported to rob $A$. mellifera colonies (Chahal et al., 1986). More important is that, the exotic honeybee species may carry pests and diseases that are suspected to drop over to a new host and infect local honeybee colonies, A. mellifera. Additionally, there is a possibility of competition for niche and forage between $A$. mellifera and $A$. florea (El Shafie et al., 2002). Moreover, A. florea was reported to prefer foraging on Prosopis spp. flowers, hence contributes positively in the production and buildup of such exotic plants (Ahmed et al., 2004; Laxen, 2007). Nevertheless, this plant contributes negatively by colonizing vast areas of agricultural lands and competes with several indigenous plant species. There is concern that $A$. florea might act as an evasive species with large impact on biodiversity in the areas invaded. Hence, it is important to investigate for the distribution (area invaded), current influence on beekeeping in the invaded areas and future ecological fear for the native $A$. mellifera and other pollinator bees. In previous studies, only little has been done regarding the species distribution, current influence on local beekeeping and future ecological fear of the invaded areas. Therefore, this study aimed to monitor the presence and to know to what extent is the exotic dwarf honeybee, A. florea, invading some districts of Tigray and Amhara Regional States of the North West and North Ethiopia. Moreover, their agro-ecologies and the negative effects they could bring on native/local honeybees, $A$. mellifera, in the areas addressed were briefly investigated.

\section{STUDY AREAS AND METHODS}

\section{Study area}

Field crops like sesame, sorghum, maize and finger millet are the most commonly cultivated crops. Five districts in Western Tigray Zone and three districts in Gondar Zone of Amhara region of Ethiopia were sampled. Most of the districts addressed in this study were covered with woodland vegetation in which Acacia and Ziziphus species were the dominant species. Field crops like sesame, sorghum, maize and finger millet are the most commonly cultivated crops.

\section{Selection of study sites}

For this study, purposive sampling was employed to identify zones that shared common boundary with Sudan where $A$. florea was introduced and well established (El Shafie et al., 2002; El-Niweiriri and Satti, 2015). Border districts and their adjoined districts in the two regional states were assessed for the invasion of the alien honeybee species.

\section{Data collection}

For the assessment of the species occurrence, three methods were employed. First questionnaires were administered to both farmer respondents consisting of beekeepers and non-beekeeper. Secondly, actively flowering flowers were observed during the study period starting early in the morning up to late in the afternoon for the presence of forager honeybees in question. Foragers were trapped with insect trapping net and identified using reference specimen of Pauly and Zewdu (2013). Finally, after confirming the presence of foragers, nests of $A$. florea were searched with the help of local beekeepers. During this assessment, data on the geographical locations of each sampling site, agro-ecology, major vegetation type, year of first observation, whether local people use their honey or not, nesting habitat, plant species used for nesting, nest position and other information were recorded. Samples of bees from three active nests and one swarm colony which was an establishing nest were taken and preserved in $97 \%$ ethanol for further observation.

\section{Data management and statistical analysis}


Data collected were entered into Microsoft excel 2007 and analyzed using SPSS version 20 . The tools used for data analysis and presentation were descriptive statistics such as percentages and frequencies analysis were employed.

\section{RESULTS AND DISCUSSION}

The study results indicated that both the beekeepers and non-beekeepers equally know the existence of unusual/alien honeybee species in their localities. Even though both the beekeepers and nonbeekeepers recognized these bees, they do not know from where it was introduced and its proper name. Rather they gave their own different local names in Tigray and Amhara Regionl States. In the latter region, the species is given the name "Kinjit" and it is called "Ye Chayna Nib" in Tigray.

Both the beekeepers and non-beekeepers responded as these honeybees are quite different from local honeybees and new for their localities. Percents' responses on the year of invasions of the districts in both regions are presented in Table 1. Most of the respondents from North Gondar Zone, Amhara Region reported that these bees arrived before the year 2007. Accordingly, 2003 is the earliest year of invasion in Metema District and it was at Kumer Aftit, about $25 \mathrm{~km}$ away the Sudanese border. However, the respondents from Tigray Regional State districts attested to more recent years than those from Metema district of Amhara Region. The years 2008, 2009, 2011 and 2012 were recorded as the first time invasion for Kefta Humera, Tsegede, Tselemti and Taytay Adyabo, respectively. These results suggest that Metema is the first district to which $A$. florea was first introduced. In addition to Meteama, $A$. florea has invaded the adjacent districts Quara and Armachew (Mirab Armachew, Tach Armachew, Lay Armachew), though its year of invasion is not clearly indicated. Figure 1 shows distribution maps of $A$. florea in Africa and Ethiopia. Similarly, Figure 2 shows the distribution map of $A$. florea in Tigray and Amhara Regions of North West Ethiopia, respectively.

Table 1: Year of invasion and districts invaded in Amhara and Tigray Regional States

\begin{tabular}{lrrrrr}
\hline & \multicolumn{5}{c}{ \% Responded per district assessed } \\
\cline { 2 - 6 } $\begin{array}{l}\text { Year } \\
\text { observed }\end{array}$ & Tselemti & Kefta & \multicolumn{4}{c}{ Taytay } \\
Humera & Tsegede & Adiyabo & Metama \\
\hline 2003 & -- & -- & -- & -- & 5 \\
2004 & -- & -- & -- & -- & 14 \\
2005 & -- & -- & -- & -- & 5 \\
2007 & -- & -- & -- & -- & 5 \\
2008 & -- & 14 & -- & -- & 0 \\
2009 & -- & 10 & 5 & -- & 5 \\
2010 & -- & 10 & -- & -- & -- \\
2011 & 5 & 5 & 5 & -- & -- \\
2012 & -- & -- & 5 & 5 & - \\
2013 & 5 & -- & -- & -- & - \\
\hline
\end{tabular}

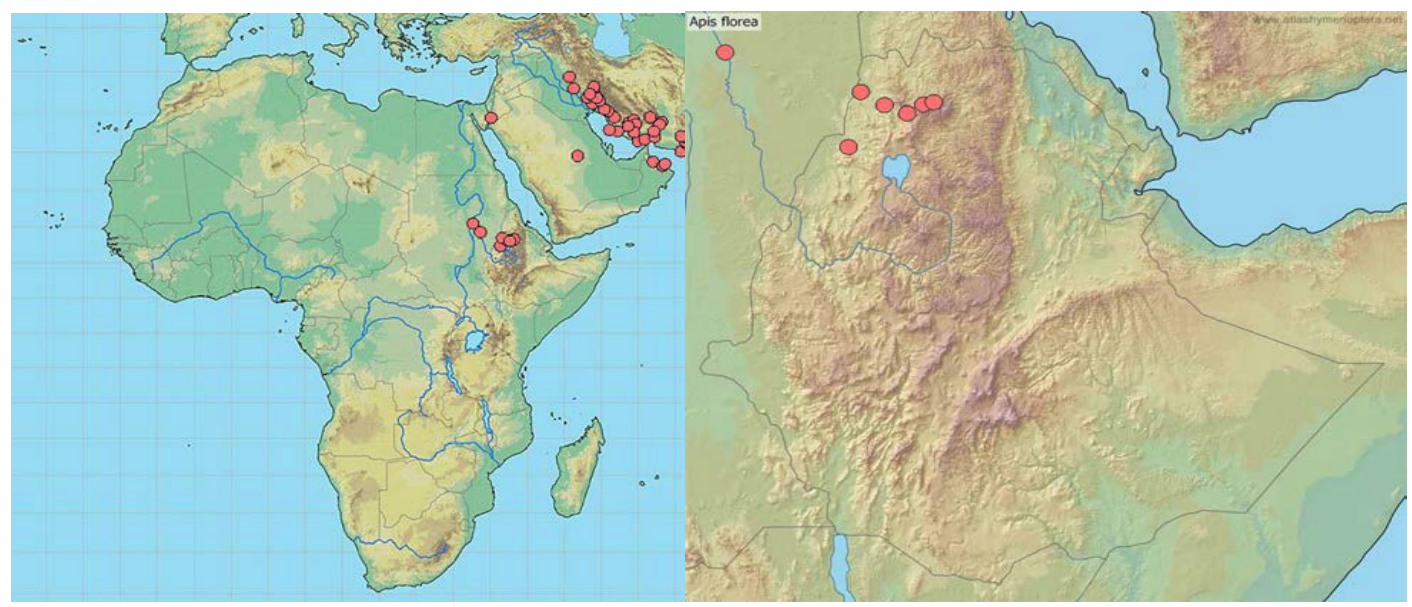

A. Distribution in Africa

B. Distribution in Ethiopia

Figure 1: Distribution Maps of $A$. florae adapted from Pauly and Zewdu (2013) 


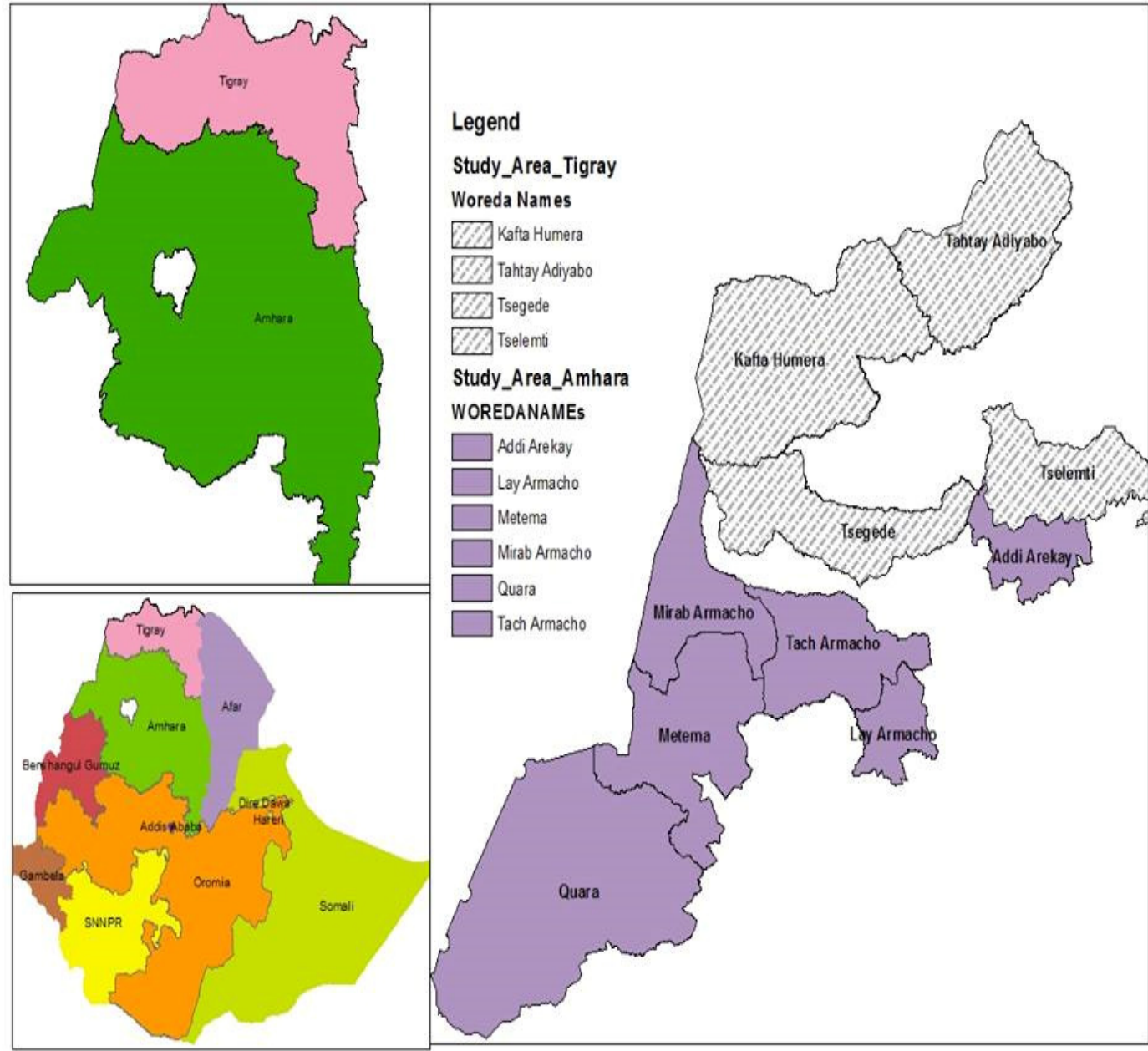

Figure 2: Distribution map of $A$. folrea in Tigray and Amhara Regions, North West Ethiopia

This bee has also recently been identified in Adi Arkay district of Amhara region to the North East Gondar (Pauly and Zewdu, 2013), and has become widely distributed in Central and Northern Tigray up to the Eritrean border (Bezabih et al., 2014). Throughout this expansion along Amhara and Tigray to Eritrean border, A. florea appears to have effectively colonized and become well adapted to the hot arid conditions of north west and north Ethiopia without being affected by the competition from local honeybees, $A$. mellifera. These evidences put forward Ethiopia as the second documented country invaded by $A$. florea in Africa next to Sudan. Regarding the bee's origin, the bees are not at all an isolated population because they have been found continuously spreading from the Sudanese border eastwards and southwards in Ethiopia, and are very probably of Sudanese origin (Bezabih et al., 2014).

A. florea has great potential to easily expand to totally new places once it is introduced either by human introduction or itself (Hepburn et al., 2005). During its expansion, it could pose threat to native bees like $A$. mellifera because they compete with same resources (Mortez et al., 2010).

The results of the survey in Table 2 indicate that colony populations of the alien honeybee are increasing in all locations since their invasions. $80 \%$ of the respondents said an increase in colony populations of $A$. florea since their introduction did not affect the colony number of local honeybees, $A$. mellifera in the studied areas. Nevertheless, the remaining percent suggested as these bees potentially affect local honeybees and their honey production through competition for forage resources. Invasive alien bees have the potential to put forth considerable direct and indirect impacts on native bees. Stout and Morales (2009) recent review proposed that there is existence of evidences of the negative impacts of invasive alien bee species on native bees. The authors outlined that major ecological impacts are mediated by competition for resource and nesting sites, transmission of pathogens, and in some cases reproductive disruption. Therefore, the spreading of $A$. florea raises some concern for apiculture since $A$. florea has shown to rob and possibly spill over a new parasitic pest to A. mellifera colonies (Chahal et al., 1986; Stout and Morales, 2009) and compete with native bees for resources (El Shafie, et al., 2002; Stout and Morales, 2009; Mortez et al., 2010).

Our assessment revealed that September to December is the time when the colony population appears and reaches its peak which is related to 
availability of bee forages in the areas. During dry months, the chance of finding the nests of $A$. florea in the assessed areas becomes less, indicating less colony population. Colony population of this alien honeybee could be an important factor. Similar phenomenon of seasonal colony population fluctuation of $A$. florea was also reported in Thailand (Olnamai and Thanee, 2004). This seasonal variation could be attributed to swarming and migration. Hepburn and
Radloff (2011) indicated that the propensity and frequency of swarming and migration are related to honeybee floral resource flow. As remarked by the local community, colony absconding is very common with these alien honeybees. Human predation/nest destruction, forage shortage and wild fire are outlined as major reasons of absconding in the areas assessed.

Table 2: Colony population trends of alien and local honeybees, and seasonal colony population fluctuation of the alien bees

\begin{tabular}{|c|c|c|c|}
\hline & \multicolumn{3}{|c|}{$\%$ of respondent } \\
\hline & Increasing & Decreasing & No change \\
\hline $\begin{array}{l}\text { Trends of alien bees' colony population since } \\
\text { introduction }\end{array}$ & 57.1 & 23.8 & 19.0 \\
\hline $\begin{array}{l}\text { Trends of local honeybee colony populations and } \\
\text { honey yield since the invasion of alien bees }\end{array}$ & 9.5 & 23.8 & 66.7 \\
\hline $\begin{array}{l}\text { Negative effects on local honeybee, } A \text {. mellifera } \\
\text { colonies }\end{array}$ & Yes (19) & No (81) & \\
\hline Alien bee colonies exist all year round & Yes (19) & No (76.2) & $\begin{array}{l}\text { Not realized } \\
(4.8)\end{array}$ \\
\hline
\end{tabular}

A. florea species is fundamentally a lowland species and it also does well in very hot, arid climates. In Ethiopia, the data for the altitudes of the localities recorded showed that it is $85.7 \%$ and $14.3 \%$ for altitudes less than $1000 \mathrm{~m}$ and greater than $1000 \mathrm{~m}$, respectively. These results are in agreement with results obtained by Hepburn (2011) through analysis of data from literatures.

Nesting habitat, plant species to nest on and nesting position on a particular plant preferred by $A$. florea were assessed. As indicated in Table 3, the bees prefer to nest on a small branch Ziziphus spp. in various nesting habitats. The results indicated that the alien honeybee, $A$. florea, had its preferential selection to build up their nests in woodland followed by farmland and farmland boundary habitats. This may be due to abundance of the availability of forage from natural vegetation and cultivated crops in these habitats. Therefore, nesting habitat preference is said to be resource dependent (Olnamai and Thanee, 2004).
We practically found four colonies, out of which two were around farm land boundaries, one in woodland and one in a village, on a fence. During the course of this assessment, a lot of foraging bees of A.florea were also observed while foraging with $A$. mellifera in the village called Horshedi (near Metema), on Ziziphus trees, and in and around farm boundaries of finger millet and sorghum, on Ziziphus spp, Guizotia scabra, Caylusea abyssinica, Cuscusta spp. (Dodder), Emilia discifolia, Peristophe paniculata, Indigofera spp. and Sida spp, in Tselemti District. Foragers of A.florea were rare early in the morning and in the late afternoon. But during late morning, almost equal numbers of foragers of both species were observed. As the time proceeded 1:00 to 2:00PM, few $A$. mellifera and a lot of A.florea foragers were observed especially on Ziziphus flower (Fig. 3). This could be related to the daily rhythms nature of the species (EI Shafie, et al., 2002). 


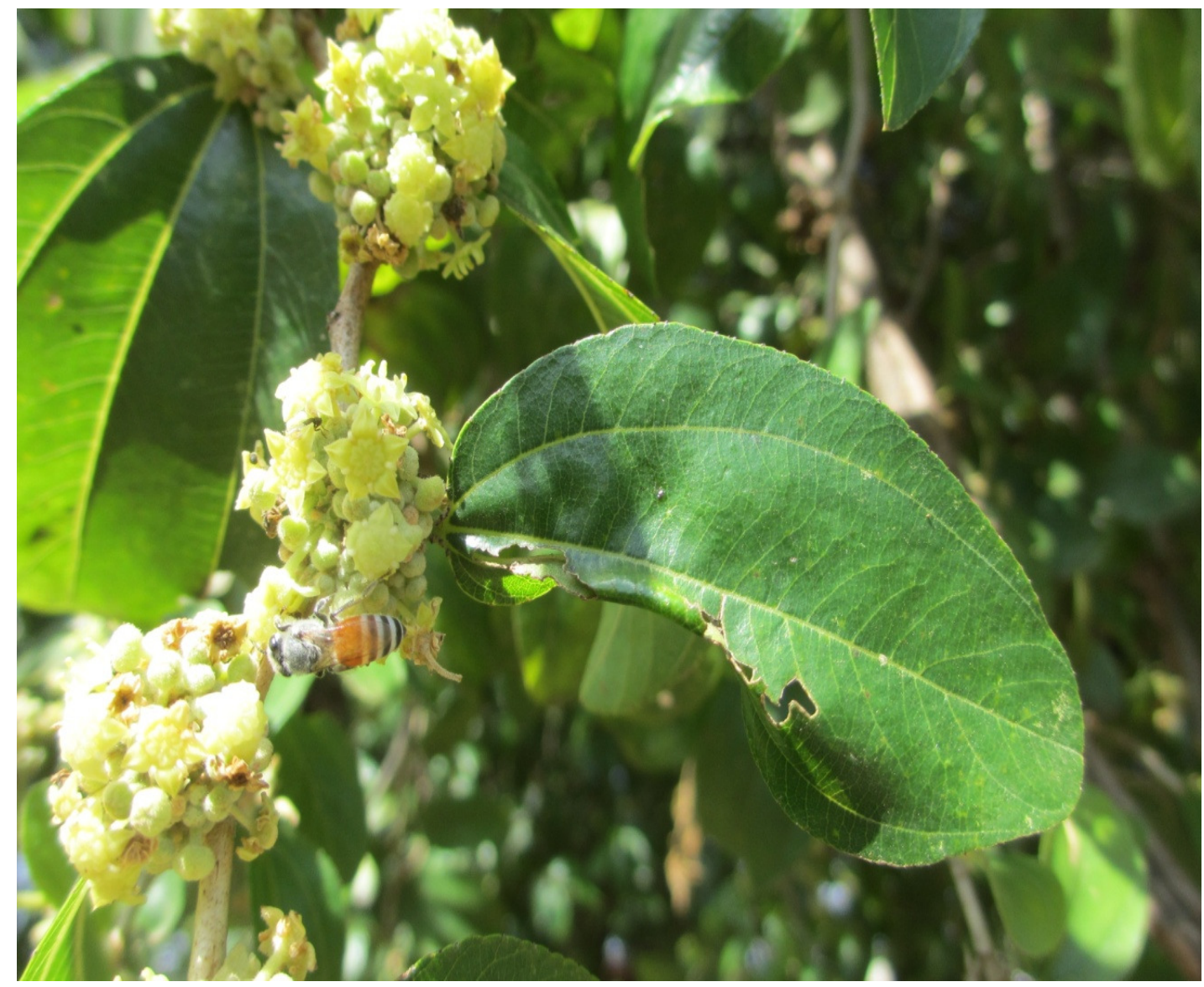

Figure 3: A.florea forager is foraging on Ziziphus flower

Concerning preference of plant species to nest on, out of the four active nests, three of them were found on dried and live Ziziphus spp. In addition, one abandoned nest was recorded on a small branch of Ziziphus spp. Most of the nests were found hanging on twigs, partly hidden and very difficult to find. These field observations were also in support of the results from the interview strengthening that $A$. florea in the assessed localities prefers small branches of Zizphus for their nesting (Table 3). However, it is not clear why they prefer Zizphus spp, hence there is need for further investigation.

Table 3: Percent responses on preference of nesting habitat, plant species to nest on and nesting position

\begin{tabular}{|l|l|l|}
\hline Ecological sites & Woodland & Preference \\
\hline Nesting habitat & Farm land & $57.1 \%$ \\
\cline { 2 - 3 } & Farm land boundary & $4.8 \%$ \\
\cline { 2 - 3 } & $\begin{array}{l}\text { Farm land and farm } \\
\text { land boundary }\end{array}$ & $28.5 \%$ \\
\hline Plants for nesting & Aye (Local name) & $4.8 \%$ \\
\cline { 2 - 3 } & Ziziphus spp. & $95.2 \%$ \\
\hline $\begin{array}{l}\text { Nesting position } \\
\text { tree/shrub }\end{array}$ & $\begin{array}{l}\text { Small branches of } \\
\text { tree/shrub }\end{array}$ & $90.5 \%$ \\
\cline { 2 - 3 } & Tree trunks & $9.5 \%$ \\
\hline
\end{tabular}

In Ethiopia, the alien honeybee species, $A$. florea colonies were observed building single comb nests whose upper part swells to form a crest that surrounds the branch from which the comb is hanged (Fig. 5). $A$. florea nests in the open, but partly hidden with dense foliage and very difficult to find unlike that of local honeybee, $A$. mellifera which is cavity nesting (Fig. 4). Unlike $A$. mellifera, these bees are not very aggressive and can stay undetected while coming closer and closer to their nest. This and the cryptic nature of the 
nests could help $A$. florea colonies to avoid nest destruction by predators including human beings.

A. florea is an open nesting eusocial honeybee species much smaller in size than cavity nesting $A$. mellifera. It also constructs only a small single comb and does not produce larger amounts of honey. In Ethiopia, the nests were 0.50 to $2.92 \mathrm{~m}$ with an average of 1.37 meters above the ground. This result is much lower than the height reported for $A$. florea in the Thailand which ranges from 0.3 to $8 \mathrm{~m}$ (Suwannapong et al., $\left.\begin{array}{llll}20 & 1 & 1\end{array}\right)$. The sizes of the sampled combs were ranging from $16 \mathrm{~cm} \times 12 \mathrm{~cm}$ to $40 \mathrm{~cm} \times 25 \mathrm{~cm}$ with an average of $28 \mathrm{~cm} \times 20.3 \mathrm{~cm}$. This finding is in agreement with report of Bezabih et al. (2014).

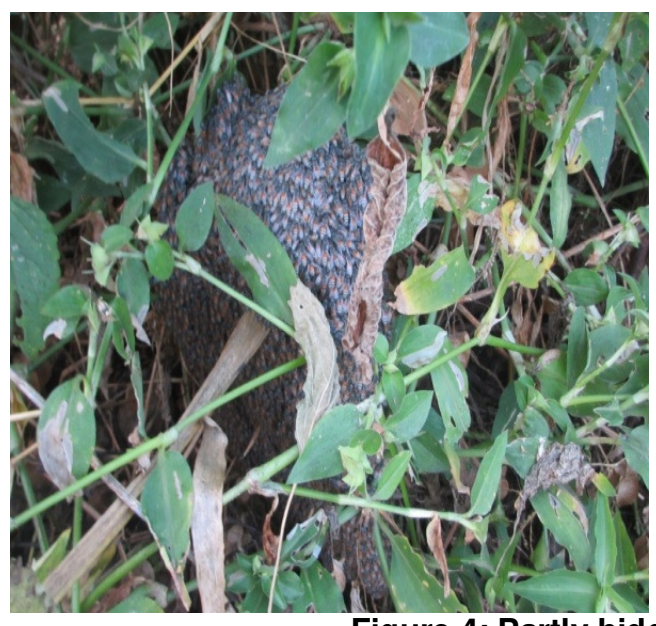

Figure 4: Partly hidden nests of $\boldsymbol{A}$. florea

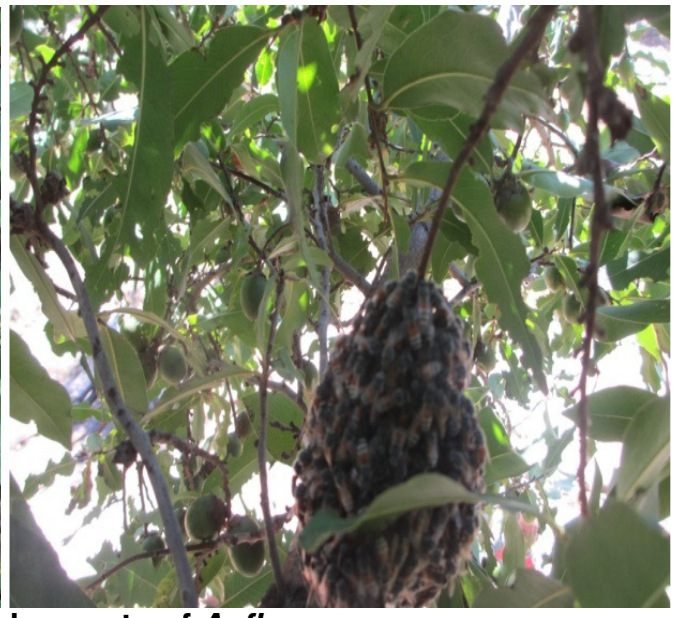

Honey and pollen were stored side by side in the crest part of the comb surrounding the small branch (Fig. 5). Honey sample was collected from honey combs (crests) of two colonies. The amount was $205.8 \mathrm{~g}$ and $265.3 \mathrm{~g}$. These figures indicated that honey production of $A$. florea is relatively very small compared to that of local honeybees, $A$. mellifera. The honey is more liquid as compared to $A$. mellifera. Unlike honey from local honeybees, $A$. mellifera, honey from $A$. florea stayed liquid for a year without a sign granulation at Holeta conditions (Personal observation). In the invaded district, the honey of $A$. florea is being used by the local communities for human consumption and for traditional medicine to treat cattle wounds.

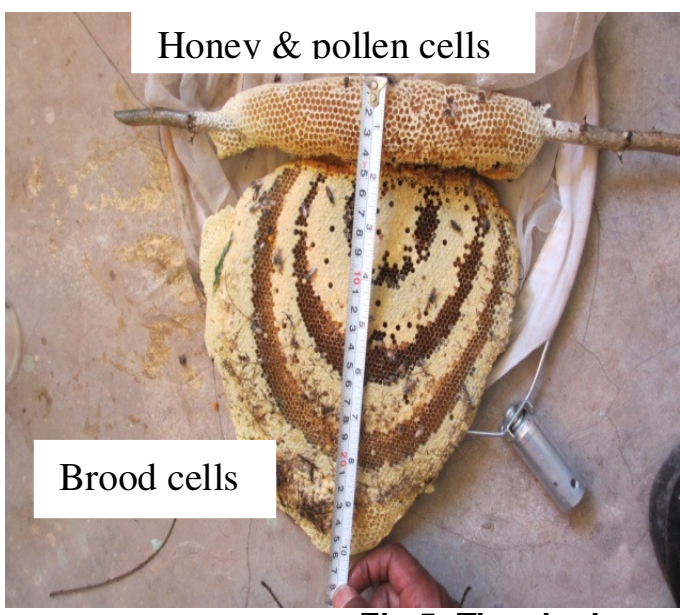

Fig 5: The single open nesting of $\boldsymbol{A}$. florea
Beneath the pollen cells the whole area of the comb was used for worker and drone brood rearing. At the bottom edge of one colony, we found about 12 queen cells with larvae indicating high swarming tendency of the species. This and other factors like migratory and comb salvage behavior of the colonies may partly elucidate the rapid expansion of $A$. florea (Pirk et al., 2011). 
Euvarroa sinhai is known as the main parasite of adult worker of $A$. florea in Asia (Mossadegh, 1991). It also parasitizes on non-Asiatic honeybees, $A$. mellifera. Fifty bee samples per colony were tested for the presence any mite. The results of washing of adult bees depicted no mite was found in all the colonies of A. florea. However, this does not guarantee nonexistence of this and other pests related to $A$. florea at all.

\section{CONCLUSION}

Based on the study results Metema could be the possible district to which $A$. florea was first introduced (2003). Since then, this alien honeybee species has become widely distributed in lowlands of north Gondar and, central and northern Tigray up to the Eritrean border. Throughout this expansion, $A$. florea appears to have effectively colonized and become well adapted to the hot arid conditions of North West and North Ethiopia without being affected by the competition from local honeybees, Apis mellifera. This natural expansion of the species poses some threat to local honeybees though majority of the respondents indicated that these bees had no negative effects on beekeeping of the areas under question. Our field observation results suggest fear for the existence of resource competition between the species as a result of niche overlap. Therefore, quick expansion of $A$. florea in the new habitat has to be monitored and more detailed research is needed to understand their ecological impacts on biodiversity of ecosystem and potentially possible economic advantages and disadvantages.

\section{AKNOWLEGEMENTS}

We thank Ethiopia Institute of Agricultural Research and Holeta Bee Research Center who financed the survey work. Special thanks are also due to Mekele Agricultural Research Center and animal husbandry experts of the addressed districts of Western Tigray and North Gondar Zones for their cooperation during the study. We thank Yohanis Mulu, a GIS expert, who helped preparing the map. Finally, we owe our genuine appreciations to the Holeta Bee Research Center staffs for their repeated support during the study.

\section{REFERENCES}

Ahmed, E.A., Mubarak, H.A. and Babiker, A.G.T. (2004). Prosopis juliflora (Swartz) DC. (Mesquite) a noxious weed in the Sudan. 1: History and prospects of chemical control. The Second National Pest Management Conference in the Sudan, 6 - 9 December 2004. Faculty of Agricultural Sciences, University of Gezira, Sudan.
Bezabih, G., Adgaba, N., Hepburn, H.R. and Pirk, C.W.W. (2014). The territorial invasion of Apis florea. African Entomology 22:888-890.

Chahal, B. S., Brar, H. S., Gatoria, G. S. and Jhajj, H. S. (1986). Aggressive behaviour of Apis florea towards Apis mellifera in hive robbing and in foraging. J. Apic. Res. 25: 134-138.

El Shafie, H.A.F, Mogga. J.B, Basedow, T. (2002). Studies on the possible competition for pollen between the honey bee, Apis mellifera sudanensis and the imported dwarf honey bee Apis florea (Hym., Apidae) in North-Khartoum (Sudan). J Appl Entomol 126:557-562.

El-Niweiri, M.A.A. Satti, A.A. (2015). Investigation on the occurrence and population densities of honeybees in Northern Sudan. Journal of Science 5: 163-168.

Hepburn, H.R. and Radloff, S.E. (2011). Biogeography of the dwarf honeybees, Apis andreniformis and Apis florae. Apidologie 42: 293-300.

Hepburn, H.R., Radloff, S.E., Otis, G.W., Fuchs, S., Verma, L.R., Tan, K., Chaiyawong, T., Tahmasebi, G. and Wongsiri, S. (2005). Apis florea: morphometrics, classification and biogeography. Apidologie 36: 359-376.

Laxen, J. (2007). Is prosopis a curse or a blessing? An ecological-economic analysis of an invasive alien tree species in Sudan. Tropical Forests Report 32. Academic dissertation. Faculty of Agriculture and Forestry of the University of Helsinki, Fabianinkatu 34, on Friday 27 April, Helsinki 2007.

Lord, W.G. and Nagi, S.K. (1987). Apis florea discovered in Africa. Bee World 68: 39-40.

Mogga G.B., Ruttner F. (1988) Apis florea in Africa; source of the founder population, Bee World 69: 100-103.

Mortez, R.F.A. and Hartel, S. (2005). Global invasions of the western honeybee

Mortez, R.F.A., Haddad, N., Bataieneh, A., Shalmon., B. and Hefetz, A. (2010). Invasion of the dwarf honeybee Apis florea into the near East. Biological Invasions 12: 1093-1099.

Mossadegh, M.S. (1991). Geographical distribution, levels of infestation and population density of the mite Euvarroa sinhai Delfinado and Baker (Acarina: Mesostigmata) in Apis florea $\mathrm{F}$ colonies in Iran. Apidologie 22: 127-134.

Olnamai, Ch. and Thanee, N. (2004). Some ecological aspects of Little Honeybee ( $A$. florea $\mathrm{F}$ ) and type sugar concentration in honey in Northeast Thailand. Pakistan Journal of Biological Sciences 7:658-661.

Omer, E. A. (2007). Studies on the taxonomy of honeybees in the Sudan. Theses and Dissertations, Agriculture, Crop protection, University of Khartoum.

Pauly, A. and Zewdu, A. H. (2013). Apini and Meliponini from Ethiopia (Hymenoptera: Apoidea: Apidae: Apinae). Belgian Journal of Entomology 16: 1-36.

Ruttner, F. (1988). Biogeography and taxonomy of honeybees. Springer, Berlin. 
Stout, J.C. and Morales, C.L. (2009). Ecological history and threats. In: Bees: Biology, Threats impacts of invasive alien species on bees. Apidologie 40: 388-409. and Colonies (Richard, M. F. ed). Nova Science Publishers, Inc. pp. 1-98.

Suwannapong, G., Benbow, M.E. and Nieh, J.C.

(2011). Biology of Thai honeybees: natural

Cite this Article: Zewdu A, Desalegn B, Amssalu B, Gebreamlak B, Tolera K (2016). Assessment of Alien Honeybee Species (Apis florea) in North West and Northern Ethiopia. Greener Journal of Agricultural Sciences, 6(3): 093-101, http://doi.org/10.15580/GJAS.2016.3.012016019. 